\title{
Children from a rural region in The Chiapas Highlands, Mexico, show an increased risk of stunting and intestinal parasitoses when compared with urban children
}

\author{
Javier Gutiérrez-Jiménez ${ }^{1 *}$, Lorena M. Luna-Cázares², Liliana Martínez-de la Cruz, \\ José A. De Aquino-López¹, David Sandoval-Gómez¹, Alejandra T. León-Ortiz¹, Juan A. Hernández-Shilón', \\ Luis A. Constantino-Jonapa ${ }^{3}$, Wilfredo A. Matamoros ${ }^{4}$ and Jorge E. Vidal ${ }^{5}$ \\ ${ }^{1}$ Laboratorio de Biología Molecular y Genética, Instituto de Ciencias Biológicas, Universidad de Ciencias y Artes de Chiapas, Tuxtla Gutiérrez, \\ Chiapas, Mexico; ${ }^{2}$ Laboratorio de Fisiología y Química Vegetal, Instituto de Ciencias Biológicas, Universidad de Ciencias y Artes de Chiapas, Tuxtla \\ Gutiérrez, Chiapas, Mexico; ${ }^{3}$ Departamento de Infectómica y Patogénesis Molecular, Centro de Investigación y de Estudios Avanzados (CINVESTAV), \\ Instituto Politécnico Nacional, Mexico City, Mexico; ${ }^{4}$ Museo de Zoología, Instituto de Ciencias Biológicas, Universidad de Ciencias y Artes de Chiapas, \\ Tuxtla Gutiérrez, Chiapas, Mexico; ${ }^{5}$ Hubert Department of Global Health, Rollins School of Public Health, Emory University, Atlanta GA, USA
}

\begin{abstract}
Background: The state of Chiapas has held the first place of extreme poverty in Mexico. The majority of Chiapas' municipalities are inhabited by marginalized, indigenous populations, who usually present diarrhea of unknown etiology. We evaluated the nutritional status, intestinal parasites, and common bacterial pathogens, including DEC (diarrheagenic Escherichia coli) strains, in 178 children under five years of age with a high (rural) and a moderate (urban) degree of marginalization. Methods: Z-scores for anthropometric indexes from the children were obtained, whereas intestinal parasites were investigated by using a direct coproparasitoscopic analysis and a concentration method. DEC strains were detected by polymerase chain reaction (PCR). Results: The stunting prevalence in children from the rural and urban regions was 79.8 and $7.5 \%$, respectively. Only children from rural municipalities were parasitized (72.6\%), being Ascaris lumbricoides and Entamoeba histolytica/Entamoeba dispar the most prevalent parasites (57.1 and 38.1\%, respectively). More than half of the children presented moderated ascariasis. Besides Giardia intestinalis, these parasites were associated with stunting. The prevalence of DEC strains was similar in both regions. Conclusions: Only children from the Chiapas Highlands (rural zone) exhibited high prevalences of stunting and intestinal parasites. A reevaluation of social development programs should be in place to address stunting and intestinal parasitoses, mainly in rural regions of Chiapas, to avoid adverse functional consequences on these children.
\end{abstract}

Key words: The Chiapas Highlands. Stunting. Ascaris lumbricoides. Entamoeba histolytica/Entamoeba dispar. Intestinal parasites.

*Javier Gutiérrez-Jiménez

E-mail: javier.gutierrez@unicach.mx

2444-3409/@ 2018. Hospital Infantil de México Federico Gómez, published by Permanyer México SA de CV, all rights reserved.
Available online: 30-10-2019 


\section{Alto riesgo de desmedro y parasitosis intestinal en niños de una región rural de los Altos de Chiapas, México, en comparación con niños de una región urbana}

\section{Resumen}

Introducción: El estado de Chiapas ha ostentado el primer lugar de pobreza extrema en México. La mayor parte de la población de los municipios de Chiapas es indígena, vive en condiciones de marginación y padece de diarrea de etiología desconocida. Este trabajo evaluó el estado nutricional, la presencia de parásitos intestinales y patógenos bacterianos comunes, además de cepas DEC (Escherichia coli diarreogénica) en 178 niños menores de cinco años, provenientes de una localidad con alto grado de marginación (rural) y de una con moderada marginación (urbana). Métodos: Se obtuvieron los puntajes $Z$ de los índices antropométricos de los niños. Los parásitos intestinales se investigaron con el método coproparasitoscópico directo y un método de concentración. Las cepas DEC se detectaron mediante reacción en cadena de la polimerasa. Resultados: La prevalencia de desmedro en niños de la zona rural y urbana fue de 79.8 y 7.5\%, respectivamente. Únicamente los niños de la zona rural estuvieron parasitados (72.6\%), y los más prevalentes fueron Ascaris lumbricoides y Entamoeba histolytica/Entamoeba dispar (57.1 y $38.1 \%$, respectivamente). Más de la mitad de los infantes exhibieron ascariasis moderada. Estos parásitos, además de Giardia intestinalis, se asociaron con el desmedro. En ambas regiones, la prevalencia de DEC fue similar. Conclusiones: Solo los niños de los Altos de Chiapas (zona rural) exhibieron alta prevalencia de desmedro y parásitos intestinales. Para evitar las consecuencias adversas entre los infantes, es necesario reevaluar los programas de desarrollo social para combatir el desmedro y la parasitosis intestinal, principalmente en las regiones rurales de Chiapas.

Palabras clave: Los Altos de Chiapas. Desmedro. Ascaris lumbricoides. Entamoeba histolytica/Entamoeba dispar. Parásitos intestinales.

\section{Introduction}

During more than a decade (2000-2013), by the records of the Mexican Ministry of Health, mild protein-energy malnutrition has been positioned as one of the top 20 diseases affecting the Mexican population. However, since 2014, this disease was removed from this list being abruptly replaced by obesity, which continues increasing ${ }^{1}$. Regarding its geographical distribution, obesity mainly affects the northern Mexican populations, while mild protein-energy malnutrition is concentrated in the southern part of the country ${ }^{1}$. The CONEVAL (for its Spanish acronym, Mexican National Council for Evaluation of Social Development Policy) pointed out that the states of Chiapas, Oaxaca, and Guerrero, in the southeast of Mexico, presented the poorest population of the country. Of these states, Chiapas was the first place of extreme poverty during 2010, 2012, 2014 and 2016, with 38.3, 32.2, 31.8 and $28.1 \%$, respectively, of their population under this condition?

Other factors that underlie poverty in these states are marginalization and economic inequality, producing its proclivity to concentrate the highest number of cases of neglected diseases ${ }^{1}$. Until 2014, mild-protein energy malnutrition figured in the list of the top 20 diseases, and it was then when obesity started affecting urban populations in Chiapas. Besides obesity, communicable diseases, such as bacterial and viral intestinal infections, intestinal amebiasis (acute amoebic dysentery, amoeboma of intestine, unspecified) and other helminthiases (schistosomiasis, echinococcosis, diphyllobothriasis and sparganosis, other cestode infections, dracunculiasis, onchocerciasis, filariasis, trichinellosis, hookworm diseases, strongyloidiasis, and enterobiasis) are still part of this list in Chiapas, mainly affecting children of 1 to 4 years of age $^{3}$.

Given the social environmental conditions, along with the high prevalence of neglected diseases, the objective of the current study was to compare and analyze the nutritional condition and the presence of intestinal parasites in children under five years of age from urban and rural zones of the state of Chiapas, which holds the first place of poverty in Mexico.

\section{Methods}

\section{Study design and population}

A cross-sectional study was performed during 2011 in the municipality of Oxchuc, a rural area located in the region of The Chiapas Highlands with nearly 43,350 inhabitants living under a high degree of marginalization (marginalization index $=1.65914$ ) besides a worrisome cultural lag $(21.47 \%$ illiterates, $31.47 \%$ of their housings are covered with earthen floors, $70.85 \%$ of households do not have running water) ${ }^{4}$. A total of $84 / 839(10.0 \%)$ children under five years of age coming 
from the localities of Cruztón ( $n=21 ; 16.5 \%)$, Tolbiljá $(n=6 ; 10.0 \%)$, Pashtonticjá $(n=8 ; 7.0 \%)$, Tzopiljá $(n=6 ; 2.3 \%)$, Lelenchij $(n=36 ; 23.4 \%)$, Stenlejtul $(n=2 ; 11.8 \%)$ and Tzunún $(n=5 ; 4.8 \%)$, all appertaining to the municipality of Oxchuc, were serviced along with their parents in the central square of each of the localities mentioned. Because the Tsotsil language is spoken in The Chiapas Highlands, the information was gathered and translated by a Tsotsil translator.

In 2012, the study area was the municipality of Chiapa de Corzo, an urban area located in the central region of the state of Chiapas. It has 87,603 inhabitants living under a moderate degree of marginalization (marginalization index $=-0.14777)$ and cultural lag $(14.23 \%$ illiterates, $12.49 \%$ of their housings are covered with earthen floors, $16.73 \%$ of their housings do not have running water) $)^{4}$. A total of $94 / 402$ children (23.3\%) under five years, whose parents agreed to participate in this study were selected from ten day-care centers located in this area: Parvulitos $(n=9 ; 22.5 \%)$, Rosario Castellanos $(n=14 ; 23.3 \%)$, Peques de ámbar $(n=10 ; 41.6 \%)$, Rehilete $(n=8 ; 21.05 \%)$, Disney $(n=17 ; 68.0 \%)$, Parachikitos $(n=2 ; 5.0 \%)$, Romeo Villanueva $(n=9 ; 20.0 \%)$, Dulces pasitos $(n=11 ; 18.3 \%)$, Jardín de las sonrisas $(n=9 ; 25.0 \%)$, and Arcoiris $(n=5$; $11.1 \%$ ). These centers are sponsored by the Mexican Ministry of Social Development (SEDESOL, for its Spanish acronym) to support single mothers, fathers, or guardians with a low income per capita that work or study and those who do not have any access to child care and nursing offered by the public social security institutions ${ }^{5}$.

Field workers only visited the houses of the parents who participated in the study (84 and 94 for Oxchuc and Chiapa de Corzo municipalities, respectively) and interviewed family members using a standardized form to collect demographic and socio-economic information including gender, age, height, weight, type of floor, and water used in their households. Field workers also collected fecal samples from each child.

In this preliminary study, a total of 178 children, 84 from Oxchuc, and 94 from Chiapa de Corzo were recruited. However, it was not a representative sample size. Among the factors that influenced the sample size of the study, some issues were beyond the control of the researchers, such as the participation conditioned to a payment, or children who did not attend the meeting point due to the poor accessibility.

\section{Nutritional assessment}

The children nutritional status was assessed with the WHO Anthro software ${ }^{6}$, using the WAZ (weight-for-age z score), the HAZ (height-for-age z score) and the WHZ (weight-for-height $\mathrm{z}$ score). Children with $\mathrm{z}$ scores $<-2$ SD (standard deviation) for WAZ, HAZ, and WHZ were classified as underweight, stunted, and wasted, respectively. Children with WHZ scores > +2 were classified as overweight?

\section{Parasitological studies}

The fecal samples were collected in sterile polypropylene tubes $(101 \times 16.5 \mathrm{~mm})$ with a screw cap and a teaspoon (Sarstedt ${ }^{\top M}$, Nümbrecht, Germany). The samples were taken and transferred to the laboratory in a cooler on the same day. Identification of intestinal parasites was made by both direct coproparasitoscopic examination and the formalin-ethyl/acetate concentration method ${ }^{8}$. The parasitic load of Ascaris lumbricoides ( $A$. lumbricoides) was determined by the modified Stoll technique as follows: $14 \mathrm{ml}$ of $\mathrm{NaOH} 0.1 \mathrm{~N}$ were placed in a graduated tube and calibrated at $15 \mathrm{ml}$ with feces. The mixture was homogenized, and $150 \mu$ were taken from the center of the suspension; the eggs were quantified at low magnification (10x) and the number of eggs per gram of feces (epg) was calculated by multiplying the number of eggs by 100 and by the correction factor, in accordance with the fecal consistency: 1.5, 2, 3 , or 4 (soft-formed, soft, loose, or watery, respectively $)^{8}$. Considering the number of $A$. lumbricoides eggs present in a gram of feces, the intensity of ascariasis was classified as mild (from 1-4,999 epg), moderate (5,000-49,999 epg) and severe (> 50,000 epg), as established by the $\mathrm{WHO}^{9}$.

\section{Identification of bacterial enteropathogens}

Fecal samples were inoculated onto MacConkey (BD BBL $^{\mathrm{TM}}$, Maryland, U.S.) and Salmonella-Shigella agar (BD BBL ${ }^{\mathrm{TM}}$, Maryland, U.S.), and incubated under aerobiosis at $37^{\circ} \mathrm{C}$ for $24 \mathrm{~h}^{10}$. Identification at the species level was performed using the $\mathrm{API}^{\circledR} 20 \mathrm{E}$ identification system (bioMérieux, Marcy l’Etoile, France). To identify DEC (diarrheagenic Escherichia coli) strains, cryopreserved Escherichia coli (E. coli) strains were further analyzed according to a established multiplex polymerase chain reaction (PCR) protocol, which amplifies specific genes of DEC or pathotypes, such as EPEC (enteropathogenic E. coli), ETEC (enterotoxigenic E. coli), EIEC (enteroinvasive E. coli), STEC (shiga-toxin producing $E$. coli) and EAEC (enteroaggregative E. coli i $)^{11,12}$. Reactions were carried out with GoTaq $^{\circledR}$ Green Master Mix, (Promega, Wisconsin, USA) in a 
Table 1. Nutritional assessment of children from different rural and urban municipalities from Chiapas, Mexico

\begin{tabular}{|l|c|c|c|c|}
\hline & Total $\mathrm{n}=178$ & Rural $\mathrm{n}=84$ & Urban $\mathrm{n}=94$ & $p$ value \\
\hline Females, $\mathrm{n}(\%)$ & 94 & $50(53.2)$ & $44(46.8)$ & 0.091 \\
\hline Males, $\mathrm{n}(\%)$ & 84 & $34(40.5)$ & $50(58.5)$ \\
\hline Household conditions & & & & \\
\hline Earthen floor, $\mathrm{n}(\%)$ & $20(100.0)$ & $18(90.0)$ & $2(10.0)$ & $<0.001$ \\
\hline No access to potable water, $\mathrm{n}(\%)$ & $89(100.0)$ & $84(94.4)$ & $5(5.6)$ & $<0.001$ \\
\hline Nutritional status & & & & \\
\hline Age* & & & & \\
\hline Height* & $2.61(1.01)$ & $2.76(1.13)$ & $2.48(0.86)$ & $<.07$ \\
\hline Weight* & $85.15(9.59)$ & $81.46(9.12)$ & $88.45(8.81)$ & 0.001 \\
\hline HAZ & $12.16(2.80)$ & $11.83(2.71)$ & $12.45(2.86)$ & 0.142 \\
\hline WAZ & $-1.72(1.75)$ & $-2.98(1.15)$ & $-0.60(1.40)$ & $<0.001$ \\
\hline WHZ & $-0.77(1.39)$ & $-1.15(1.32)$ & $-0.43(1.37)$ & $<0.001$ \\
\hline Stunted, $\mathrm{n}(\%)$ & $0.29(1.66)$ & $0.77(1.77)$ & $-0.14(1.44)$ & $<0.001$ \\
\hline Underweight, $\mathrm{n}(\%)$ & $74(41.8)$ & $67(79.8)$ & $7(7.5)$ & $<0.001$ \\
\hline Wasted, $\mathrm{n}(\%)$ & $26(14.6)$ & $16(19.0)$ & $10(10.6)$ & 0.134 \\
\hline Obese, $\mathrm{n}(\%)$ & $8(4.5)$ & $2(2.4)$ & $6(6.4)$ & 0.278 \\
\hline
\end{tabular}

*Mean $( \pm \mathrm{SD})$.

HAZ, height-for-age z score; WAZ, weight-for-age zscore; WHZ, weight-for-height z score; SD, standard deviation.

final volume of $25 \mu$ l. PCR products were resolved by electrophoresis with TAE (Tris/acetic acid/EDTA) buffer 1X (Promega, Wisconsin, USA) on $2.5 \%$ agarose gels. Gels were stained with an ethidium bromide solution $0.5 \mu \mathrm{g} / \mathrm{ml}$ (Bio-Rad, California, USA) and the PCR products were observed in a gel documentation system (Enduro ${ }^{\text {TM }}$ GDS, New Jersey, USA).

\section{Statistical analysis}

To obtain the frequencies, mean, and standard deviation of the independent (age, weight, height, $H A Z$, WAZ, WHZ z scores, intestinal parasites and E. coli pathotypes prevalence, parasitic load by $A$. lumbricoides, housings with earthen or cement floor, children consuming running or potable water) and dependent (malnutrition, intestinal parasites) variables, the study relied on the use of descriptive statistics. With the purpose of assessing the normal distribution of the data, the Kolmogorov-Smirnov test was used. The means of the independent variables were compared through the Student's $t$-test, while the Pearson's correlation coefficient was used to test the association between stunting and age. The analysis among dependent variables in rural and urban regions was evaluated by the $\chi^{2}$ or the Fisher's exact tests. The relation among the region of residence/stunting were assessed through the Phi coefficient. The odds ratio (OR) was calculated for the variables stunting and region/type of intestinal parasites with a $95 \%$ confidence interval. For all the analyses, significant value was established as $p \leq 0.05$ using the SPSS software, version 20 (Armonk, New York, IBM Corp.).

\section{Results}

\section{Nutritional assessment}

The mean age of children was $2.6 \pm 1.01$ years and $52.8 \%$ of the enrolled children were females $(p>0.5)$. The mean weight and height were $12.1 \pm 2.80 \mathrm{~kg}$ and $0.85 \pm 9.59 \mathrm{~m}$, respectively. The mean height of children from the rural municipality was significantly lower than that of children living in the urban region $(p<0.01)$. Accordingly, the HAZ score presented significant differences in children from the rural zone with an average of almost $-3 \mathrm{SD}$, indicating that rural children had severe stunting (Table 1).

Moreover, the stunting prevalence in children from the rural zone was almost $70 \%$ and less than $10 \%$ in the urban zone (Table 1). The Phi correlation coefficient $(-0.73)$ revealed that living in the rural municipality was significantly associated with children stunting $(p<0.001)$. Thus, children from Oxchuc (rural municipality) had $\sim 50$-fold higher risk of stunting compared with those from Chiapa de Corzo (urban municipality) 
Table 2. HAZ scores by age-group and sex among children from Chiapas, Mexico

\begin{tabular}{|l|c|c|c|}
\hline \multirow{2}{*}{ Age group (months) } & \multicolumn{2}{|c|}{ HAZ scores Mean (SD) } & \multirow{2}{*}{ p value } \\
\cline { 2 - 3 } & Rural & Urban & \\
\hline $6-11$ & $-1.86(1.36)$ & $1.77(4.43)$ & 0.1736 \\
\hline $12-23$ & $-3.29(1.35)$ & $-0.65(1.23)$ & $<0.001$ \\
\hline $24-35$ & $-2.62(0.86)$ & $-0.74(1.00)$ & $<0.001$ \\
\hline $36-47$ & $-3.40(1.13)$ & $-0.72(1.58)$ & $<0.001$ \\
\hline $48-60$ & $-3.04(0.98)$ & $-0.38(1.50)$ & $<0.001$ \\
\hline $\begin{array}{c}\text { Gender } \\
\text { Female } \\
\text { Male }\end{array}$ & $-3.01(1.15)$ & $-0.69(1.56)$ & $<0.001$ \\
\hline
\end{tabular}

HAZ, height-for-age z score; SD, standard deviation.

(OR $=48.4$ 18.98-123.50]). According to the age, HAZ scores of children from the rural municipality were significantly lower than those from the urban zone. These differences were observed in most age groups including those from 12 months to 5 years of age (Table 2); the values of this indicator were lower according to the growth of the children. However, there was no direct relation between stunting and the ages of the children living in the rural municipality $\left(R^{2}=0.018\right)$.

\section{Prevalence of intestinal parasites}

The overall prevalence of intestinal parasitosis was $34 \%$. However, only children from Oxchuc were affected by those organisms, with a high prevalence $(72 \%)$. The most prevalent parasite was A. lumbricoides (57\%), being the most frequent the moderate $(20,564.7 \pm$ $13,634.5 \mathrm{epg})$, followed by the light $(3,075 \pm 1,443.9$ epg), and the severe $(97,900 \pm 38,932.9 \mathrm{epg})$ ascariasis (Table 3). The most prevalent protozoa were Entamoeba histolytica (E. histolytica)/Entamoeba dispar (E. dispar) and Giardia intestinalis (G. intestinalis) (38.1 and $16.7 \%$, respectively) (Table 3). The E. histolytica/E. dispar term is used throughout this manuscript. An additional molecular method should be used for the specific identification of E. histolytica or E. dispar ${ }^{13}$. Unfortunately, this molecular assay is not available in our laboratory.

The analysis showed a significant association between the presence of $A$. lumbricoides, E. histolytica/E. dispar, or G. intestinalis with stunting of children from Oxchuc (rural). These children showed a 10-fold higher risk of stunting due to being parasitized with these agents (Table 4).

Regarding bacterial pathogens, no Shigella species were isolated, and a very low prevalence of Salmonella spp. was identified among these children. Moreover, DEC strains were isolated in $16.3 \%$ of children (Table 3 ). There was no significant association between the isolation of DEC strains from children from Oxchuc with a high prevalence of malnutrition. Neither among children from Chiapa de Corzo with a low prevalence of nutritional alterations (Table 1). Among DEC strains, EAEC and EPEC pathotypes were the most frequently isolated in both regions with only a few cases of ETEC strains (Table 3). STEC and DAEC strains were not isolated in this study.

\section{Discussion}

In the rural zone, the prevalence of stunting (70\%) was even greater than the one reported previously in a study conducted in Chiapas (54.1\%), where children experienced social conflicts caused by land tenure and religious differences ${ }^{14}$. In addition to these factors, extreme poverty in this region continues sharpening the malnutrition problem of children. As mentioned above, since 2010, Chiapas holds the first place of extreme poverty in Mexico?

A previous study conducted by our group, with preschool children from the municipalities of Larrainzar and Chanal (at The Chiapas Highlands), revealed stunting prevalences of $55.1 \%$ and $70 \%$, respectively. Similarly to the current study, the socioeconomic conditions were associated with stunting in Larrainzar and Chanal15. Another factor that could explain the recurrent children malnutrition in rural Chiapas is the intergenerational cycle phenomenon observed in these regions. A study performed with two generations of brothers under five years of age in the region known as De Los Bosques (an indigenous area with high marginalization located beside The Chiapas Highlands), showed a stunting prevalence of $\sim 50 \%{ }^{16}$.

It has been hypothesized that when food supplies are scarce, mothers and daughters of indigenous families from rural zones of Chiapas reduce the intake of food for the benefit of the father and sons ${ }^{17}$. This hypothesis was not confirmed in this research: although the HAZ scores from the girls of rural municipalities were lower than those from boys (Table 2), such difference was not significant $(p=0.7423)$. This trend, however, was similar to the one reported by a study performed with 1,160 children under five years of age in three different 
Table 3. Enteric pathogens in children from different rural and urban municipalities from Chiapas, Mexico

\begin{tabular}{|c|c|c|c|c|}
\hline Parasitological profile & Total n (\%) & Rural n (\%) & Urban n (\%) & $p$ value \\
\hline Intestinal parasites & $61(34.3)$ & $61(72.6)$ & $0(0.0)$ & $<0.001$ \\
\hline Monoparasites (one species) & $27(15.2)$ & $27(32.1)$ & $0(0.0)$ & \\
\hline Polyparasites (>1 species) & $34(19.1)$ & $34(40.5)$ & $0(0.0)$ & \\
\hline Ascaris lumbricoides & $48(27.0)$ & $48(57.1)$ & $0(0.0)$ & $<0.001$ \\
\hline \multicolumn{5}{|l|}{ Type of ascariasis } \\
\hline $\begin{array}{l}\text { aSevere } \\
{ }^{\mathrm{b} M o d e r a t e} \\
\text { 'Mild } \\
\text { Trichuris trichiura } \\
\text { Hymenolepis nana } \\
\text { Enterobius vermicularis } \\
\text { Entamoeba histolytica/Entamoeba dispar } \\
\text { Giardia intestinalis }\end{array}$ & $\begin{array}{c}- \\
- \\
- \\
6(3.4) \\
7(3.9) \\
1(0.6) \\
32(18.0) \\
14(7.9)\end{array}$ & $\begin{array}{l}4(11.4) \\
18(51.4) \\
13(37.1) \\
6(7.1) \\
7(8.3) \\
1(1.2) \\
32(38.1) \\
14(16.7)\end{array}$ & $\begin{array}{c}- \\
- \\
- \\
0(0.0) \\
0(0.0) \\
0(0.0) \\
0(0.0) \\
0(0.0)\end{array}$ & $\begin{array}{c}- \\
- \\
- \\
0.01 \\
0.005 \\
0.472 \\
<0.001 \\
<0.001\end{array}$ \\
\hline \multicolumn{5}{|l|}{ Bacterial pathogens } \\
\hline $\begin{array}{l}\text { Salmonella spp. } \\
\text { Shigella spp } \\
\text { Escherichia coli DEC } \\
\text { E. coli EAEC } \\
\text { E. coli EPEC } \\
\text { E. coli ETEC }\end{array}$ & $\begin{array}{c}1(0.6) \\
0(0.0) \\
29(16.3) \\
14(7.9) \\
10(5.6) \\
5(2.8)\end{array}$ & $\begin{aligned} 0 & (0.0) \\
0 & (0.0) \\
16 & (19.1) \\
7 & (8.3) \\
5 & (6.0) \\
4 & (4.8)\end{aligned}$ & $\begin{aligned} 1 & (1.1) \\
0 & (0.0) \\
13 & (13.8) \\
7 & (7.4) \\
5 & (5.3) \\
1 & (1.1)\end{aligned}$ & 0.418 \\
\hline
\end{tabular}

Stratification of intensity of $A$. lumbricoides infection': a severe ascariasis: $>50,000$ eggs per gram (epg): ${ }^{b}$ moderate ascariasis: $5,000-49,999$ epg; ${ }^{c}$ mild ascariasis: $1-4,999$ epg. $\mathrm{DEC}$, diarrheagenic Escherichia coli (E. coli); EAEC, enteroaggregative E. coli; EPEC, enteropathogenic E. coli; ETEC, enterotoxigenic E. coli.

Table 4. Association among intestinal parasites and stunting in children from Oxchuc, Chiapas, Mexico

\begin{tabular}{|l|c|c|c|c|}
\multirow{2}{*}{ Intestinal parasite } & \multicolumn{2}{|c|}{ Height-for-age categories } & \multirow{2}{*}{$\mathrm{p}$ value } & \multirow{2}{*}{ OR (95\% CI) } \\
\cline { 2 - 5 } & Stunted $\mathrm{n}(\%)$ & Normal $\mathrm{n}(\%)$ & & \\
\hline Ascaris lumbricoides & $38(79.2)$ & $10(20.8)$ & $<0.001$ & $9.81(4.43-21.75)$ \\
\hline Entamoeba histolytica/Entamoeba dispar & $26(81.2)$ & $6(18.8)$ & $<0.001$ & $8.75(3.37-22.70)$ \\
\hline Giardia intestinalis & $12(85.7)$ & $2(14.3)$ & 0.001 & $9.77(2.11-45.13)$ \\
\hline
\end{tabular}

$\mathrm{OR}$, odds ratio; $\mathrm{Cl}$, confidence interval.

regions of Chiapas (including The Chiapas Highlands). In this study, the averages of HAZ scores were $-1.08,-2.3,-2.7,-2.9$, and -2.86 for children of $0-11$, 12-23, 24-35, 36-47 and 48-59 months, respectively ${ }^{18}$. The current findings show a decrease of almost twice in the HAZ score in the 12-23 month-old group in comparison with the 6-11 month-old group (Table 2). The observed difference can be attributed to these related factors. Infants of 6-11 months of age are still breastfed, whereas those of 12-23 months of age have ended breastfeeding and initiated their intake of nutrients through scarce and low-quality food provided in their households ${ }^{19}$.
In 2014, the Mexican government launched a social program called PROSPERA, which included decreasing hunger and ending the intergenerational cycle of poverty suffered by the populations of the Southeast of the country as its main goals ${ }^{1}$. The documented evidence suggests low progress of this program. For example, a nine-year study that included 222 indigenous children enrolled in PROSPERA, and children who did not enroll in the program, both from the same marginalized localities of De Los Bosques, revealed a stunting prevalence of $40.1 \%$ and $69.6 \%$, respectively. Furthermore, $34.5 \%$ of children with normal nutritional status $(n=110)$ presented stunting after two years, and 
five years later, the percentage increased to $52.6 \%{ }^{20}$. Another study carried out in the same region, which enrolled two generations of brothers of preschool age who were beneficiaries of that government program, revealed $43.4 \%$ of stunting, $13.2 \%$ of underweight and $10.4 \%$ of wasting ${ }^{16}$.

In addition to monitoring the children's growth during the first three years of life ${ }^{19}$, it is important to implement policies emanating from the Lancet scientists group, which study mother-to-child nutrition. Regarding preventive actions against diseases, deworming, prevention of obesity, adequate hydration during diarrheal episodes, hygiene and remedial measures should be considered ${ }^{21}$.

In the present report, a high prevalence of intestinal parasites among children under five years old living in the Chiapas Highlands was shown. Previous studies, including one from the 50's, have documented that the rural population in Chiapas has suffered continuously from intestinal parasitosis ${ }^{22}$. Previous research, conducted in the municipality of Chanal (The Chiapas Highlands) with children under five years of age, revealed a similar prevalence of parasitosis $(47 \%)$ as this work, being also $A$. lumbricoides the most prevalent $(45 \%)^{15}$. When a population from the Chiapas border with Guatemala was studied, authors found out an even higher prevalence $(85.5 \%)$ of intestinal parasites. Similarly, $A$. lumbricoides was the parasite most frequently identified $(45.5 \%)$ in inhabitants of the Guatemalan border, followed by Ancylostomatidae and Trichuris trichiura (37\% and $36 \%$, respectively), as well as the protozoa E. histolytica and G. intestinalis (19.4 and 15.6\%, respectively) ${ }^{23}$.

In the state of Chiapas, intestinal amebiasis is still within the top 20 causes of disease with $3.5 \times 10^{4}$ and $3.2 \times 10^{4}$ cases reported in 2011 and 2012, respectively. This prevalence did not change dramatically in 2016, where $2.1 \times 10^{4}$ cases were reported. A similar trend is observed with ascariasis, a parasitosis which causes morbidity in the state with $6.0 \times 10^{3}, 4.9 \times 10^{3}$, and $3.7 \times 10^{3}$ cases reported in 2011, 2012, and 2016, respectively $^{3}$. The high prevalence of intestinal parasites in children from Oxchuc (rural) but not in those living in Chiapa de Corzo (urban) may be, in part, attributed to a lack of potable water. A study carried out in a marginalized region of the border of Chiapas with Guatemala revealed an association between $E$. histolytica and the bad quality of the water usually drunk in those housings ${ }^{24}$. The previously mentioned socioeconomic differences between the rural and urban regions may explain the high prevalence of intestinal parasitosis in
Oxchuc (rural) and its absence in Chiapa de Corzo (urban). In agreement with the mentioned hypothesis, a recent work carried out in the metropolitan areas of Brazil revealed that the geospatial distribution of parasitic intestinal infections was associated with regions with higher social vulnerability ${ }^{25}$. A previous study conducted in another marginalized municipality of northern Chiapas, Pantepec, also revealed that intestinal parasitosis (mainly ascariasis) was associated with malnutrition in children under five years of age ${ }^{15}$. More evidence linking infection with parasites and health complications was recently provided in a study, showing an association between intestinal infection with Necator americanus and anemia among women from Altamirano, Chiapas (The Chiapas Highlands) ${ }^{26}$.

Regarding the bacterial enteropathogens, the presence of EAEC and EPEC has been described in both healthy children and children with diarrhea ${ }^{27}$. Therefore, it necessary to determine the bacterial load in children with and without diarrhea, with the purpose of establishing its role as pathogens ${ }^{28}$. Salmonella spp. was only recovered from a child from Chiapa de Corzo. The very low prevalence of classic bacterial intestinal pathogens was not a surprise given that children did not show acute diarrhea and, besides their nutritional status and high prevalence of intestinal parasites, were considered otherwise healthy. In the present study, an enrichment step to culture bacterial intestinal pathogens was not used. However, if utilized, the prevalence of these bacterial species may not have changed significantly.

The low isolation rate of Salmonella spp. demonstrated in this study was similar to the one reported in Yucatan (Mexico), although the isolation rate of DEC strains doubled. The mentioned study enrolled 831 children under five years of age with diarrhea. The prevalence of DEC (28\%) exceeded the one of Salmonella and Shigella (12 and 9\%, respectively), and diffusely adherent E. coli (DAEC), EAEC and EPEC were the most frequent $E$. coli pathotypes $(35,24$, and $19 \%$, respectively $)^{29}$. Another study conducted in 1,037 patients with diarrhea from different regions of Sinaloa (Northeast of Mexico) showed a DEC prevalence of $23.3 \%$; also, EAEC and EPEC were the most frequently isolated (12.2 and $5.1 \%$, respectively) ${ }^{30}$.

The findings in this work showed a great disparity in the nutritional status and the presence of intestinal parasites among children from two municipalities of Chiapas, which was associated with their marginalization status, high versus moderate. Our conclusion should be taken with caution because of the non-representative sample size, as explained earlier. Most of Chiapas' 
municipalities ( $n=118,80 \%$ ) have been classified with very high and high marginalization degrees (40.68 and $33.05 \%$, respectively) ${ }^{31}$. From the assessed nutritional status, stunting had an elevated prevalence in children from the rural region of Oxchuc, besides being the children in which almost $80 \%$ presented intestinal parasitosis, mainly caused by $A$. lumbricoides and $E$. histolytica/E. dispar. Such parasitoses were associated with stunting in children from rural zones. It is worth mentioning that most of their households lack access to potable water. These data revealed that marginalized, rural municipalities of Chiapas are still vulnerable to malnutrition and other neglected diseases as ascariasis. Consequently, it seems necessary to reassess the current programs offered by the state and federal government, which are trying to fight against hunger in such populations, and adopt other efforts aimed at improving the socio-environmental conditions for diminishing the high index of these diseases among the marginalized populations of developing countries such as Mexico.

\section{Ethical disclosures}

Protection of human and animal subjects. The authors declare that no experiments were performed on humans or animals for this study.

Confidentiality of data. The authors declare that they have followed the protocols of their work center on the publication of data.

Right to privacy and informed consent. The authors declare that no patient data appear in this article.

\section{Acknowledgments}

To QFB María Dolores Toledo Meza and TLC Patricia Ramírez Cobaxin for the technical support, and to Adaneli Torres Gómez for the management and administrative support.

\section{Conflicts of interest}

The authors declare no conflicts of interest.

\section{Funding}

1) Instituto de Tecnologías Rurales, A.C. and Eoz, S.A. de C.V. (grant number FCB-201211; La Paz, Baja California Sur, Mexico); 2) Instituto Carlos Slim de la
Salud (grant number ICS-2011); 3) Secretaría de Desarrollo Social (grant number CHIS-101-12).

\section{References}

1. Gutiérrez-Jiménez J, Luna-Cazáres LM, Vidal JE. Malnutrition and Intestinal Parasites: Mexico Perspectives. In: Preddy VR, Patel VB, editors. Handbook of famine, starvation, and nutrient deprivation. From biology to policy. Geneva: Springer International Publishing; 2017. pp. 1-18.

2. coneval.org [Internet]. Consejo Nacional de Evaluación de la Política de Desarrollo Social (CONEVAL). Medición de la pobreza 2008-2016. Available at: https://www.coneval.org.mx/Paginas/principal.aspx

3. salud.gob.mx [Internet]. Anuario de morbilidad 1984-2016. Secretaría de Salud. Available at: http://www.epidemiologia.salud.gob.mx/anuario/html/ anuarios.html

4. salud.gob.mx [Internet]. Catálogo de localidades. Secretaría de DesarroIlo Social. Available at: http://www.microrregiones.gob.mx/catloc

5. gob.mx [Internet]. Programa de Estancias Infantiles para Apoyar a Madres Trabajadoras. Secretaría de Desarrollo Social. Available at: https:// www.gob.mx/sedesol/acciones-y-programas/estancias-infantiles-para-apoyar-a-madres-trabajadoras

6. who.int [Internet]. WHO AnthroPlus software Geneva, Switzerland: World Health Organization. Available at: http://www.who.int/growthref/tools/en

7. Onyango A, De Onis M, Organization WH. WHO child growth standards: training course on child growth assessment [Internet]. Geneva: WHO; 2008. Available at: http://www.who.int/iris/handle/10665/43601.

8. García LS, Campbell J, Fritsche TR, Hummert B, Johnston SP, Rachford FW, et al. Procedures for the recovery and identification of parasites from the intestinal tract: approved guideline. Pennsylvania: Clinical and Laboratory Standards Institute; 2005.

9. WHO Expert Committee on the Control of Schistosomiasis. Prevention and control of schistosomiasis and soil-transmitted helminthiasis. Geneva: World Health Organization. Available at: http://www.who.int/iris/handle/10665/42588

10. Vila J, Álvarez-Martínez MJ, Buesa J, Castillo J. Diagnóstico microbiológico de las infecciones gastrointestinales. Enferm Infecc Microbiol Clin. 2009;27:406-11.

11. Cerna JF, Nataro JP, Estrada-Garcia T. Multiplex PCR for detection of three plasmid-borne genes of enteroaggregative Escherichia coli strains. $\mathrm{J}$ Clin Microbiol. 2003;41:2138-40.

12. López-Saucedo C, Cerna JF, Villegas-Sepulveda N, Thompson R, Velazquez FR, Torres J, et al. Single multiplex polymerase chain reaction to detect diverse loci associated with diarrheagenic Escherichia coli. Emerg Infect Dis. 2003;9:127-31.

13. Gonin P, Trudel L. Detection and differentiation of Entamoeba histolytica and Entamoeba dispar isolates in clinical samples by PCR and enzyme-linked immunosorbent assay. J Clin Microbiol. 2003;41:237-41.

14. Sánchez-Pérez HJ, Hernán MA, Ríos-González A, Arana-Cedeño M, Navarro A, Ford D, et al. Malnutrition among children younger than 5 years-old in conflict zones of Chiapas, Mexico. Am J Public Health. 2007;97:229-32.

15. Gutierrez-Jimenez J, Torres-Sanchez MGC, Fajardo-Martinez LP, Schlie-Guzman MA, Luna-Cazares LM, Gonzalez-Esquinca AR, et al. Malnutrition and the presence of intestinal parasites in children from the poorest municipalities of Mexico. J Infect Dev Ctries. 2013;7:741-7.

16. Garcia-Parra E, Ochoa-Diaz-Lopez H, Garcia-Miranda R, Moreno-Altamirano L, Morales H, Estrada-Lugo ElJ, et al. Nutritional status of two generations of brothers and sisters $<5$ years of age beneficiaries from opportunities living in marginalized rural communities in Chiapas, Mexico. Nutr Hosp. 2015;31:2685-91.

17. Martínez-Rodríguez JC, García-Chong NR, Trujillo-Olivera LE, Noriero-Escalante L. Food insecurity and social vulnerability in Chiapas: the face of poverty. Nutr Hosp. 2015;31:475-81.

18. Ochoa-Diaz Lopez H, Garcia-Parra E, Flores-Guillen E, Garcia-Miranda R, Solis-Hernandez R. Evaluation of the nutritional status of children under 5 years of age: concordance between anthropometric indices in the indigenous population of Chiapas (Mexico). Nutr Hosp. 2017;34:820-6.

19. Prendergast AJ, Humphrey JH. The stunting syndrome in developing countries. Paediatr Int Child Health. 2014;34:250-65.

20. García-Parra E, Ochoa-Díaz-López H, García-Miranda R, Moreno-Altamirano L, Solís-Hernández R, Molina-Salazar R. Are there changes in the nutritional status of children of Oportunidades families in rural Chiapas, Mexico? A cohort prospective study. J Health Popul Nutr. 2016;35:1.

21. Bhutta ZA, Das JK, Rizvi A, Gaffey MF, Walker N, Horton S, et al. Evidence-based interventions for improvement of maternal and child nutrition: What can be done and at what cost? Lancet. 2013:382:452-77.

22. Markell E, Chavez Nunez M. Intestinal parasitic infections among the inhabitants of a coffee plantation \& a village in Chiapas, Mexico. Rev Inst Salubr Enferm Trop. 1956;16:43-9. 
23. Martinez Garcia C, Guiscafre Gallardo H, Huerta Munoz A, Barreto Fernandez de Lara JA, Moreno Altamirano L, Flores Huerta S, et al. Intestinal parasitoses in Guatemalan refugees and in the rural Mexican population in Chiapas. Salud Publica Mex. 1987;29:33-40.

24. Sanchez-Perez HJ, Vargas-Morales MG, Mendez-Sanchez JD. Bacteriological quality of human drinking water in high-margination zones in Chiapas. Salud Publica Mex. 2000;42:397-406.

25. Faria CP, Zanini GM, Dias GS, da Silva S, de Freitas MB, Almendra R, et al. Geospatial distribution of intestinal parasitic infections in Rio de Janeiro (Brazil) and its association with social determinants. PLoS Negl Trop Dis. 2017:11:e0005445.

26. Brentlinger PE, Capps L, Denson M. Hookworm infection and anemia in adult women in rural Chiapas, Mexico. Salud Publica Mex. 2003;45:117-9.

27. Estrada-Garcia T, Navarro-Garcia F. Enteroaggregative Escherichia coli pathotype: a genetically heterogeneous emerging foodborne enteropathogen. FEMS Immunol Med Microbiol. 2012;66:281-98.
28. Barletta F, Ochoa TJ, Mercado E, Ruiz J, Ecker L, Lopez G, et al. Quantitative real-time polymerase chain reaction for enteropathogenic Escherichia coli: a tool for investigation of asymptomatic versus symptomatic infections. Clin Infect Dis. 2011;53:1223-9.

29. Patzi-Vargas S, Zaidi MB, Perez-Martinez I, Leon-Cen M, Michel-Ayala A, Chaussabel D, et al. Diarrheagenic Escherichia coli carrying supplementary virulence genes are an important cause of moderate to severe diarrhoeal disease in Mexico. PLoS Negl Trop Dis. 2015;9: e0003510.

30. Canizalez-Roman A, Flores-Villasenor HM, Gonzalez-Nunez E, Velazquez-Roman J, Vidal JE, Muro-Amador $S$, et al. Surveillance of diarrheagenic Escherichia coli strains isolated from diarrhea cases from children, adults and elderly at Northwest of Mexico. Front Microbiol. 2016;7:1924.

31. inegi.org [Internet]. Instituto Nacional de Estadística y Geografía (INEGI). 2017. Available at: http://www.inegi.org.mx. 